Article

\title{
Forecast of growth and development of modal fir stands in the lower Angara region
}

\author{
Pavel V Mikhaylov ${ }^{1 *}$, Sveylana M Sul'tson ${ }^{1}$, and Andrey A Goroshko ${ }^{1}$ \\ 1 Reshetnev Siberian State University of Science and Technology, Krasnoyarskii rabochii prospekt. 31, \\ Krasnoyarsk, 660037, Russia; mihaylov.p.v@mail.ru (P.V.M.); sultson2011@yandex.ru (S.M.S.); \\ utrom3@gmail.com (A.A.G.) \\ * Correspondence: mihaylov.p.v@mail.ru ; Tel.: +7-950-995-17-74 (P.V.M.)
}

\begin{abstract}
The paper presents an assessment of the growth dynamics of the modal fir plantations in the Lower Angara region. At present, a vast area of fir forests in the Lower Angara region is characterised by a significant decrease in sustainability due to periodic forest fires, insect pests outbreaks and diseases, which lead to their natural degradation and death. However, the intensity of coniferous stand growth in certain forest site characteristics persists in the long term. Therefore, creating regression models of forest growth and development involving the identification of site conditions is very important both from a practical point of view and for environmental monitoring. The materials of the mass inventory of 3491 stands served as the initial data for studying the processes of fir plantations natural growth. The Hoerl Model function is suitable for the best approximation of stand growth since it is characterised by high levelling factor (from 0.970 to 0.987 ) and a small standard error (not exceeding 7\%). As a result of the research, there have been constructed sketches of the growth rate tables for the modal Siberian fir stands of the third bonitet class of the forb and mossy groups of forest types.
\end{abstract}

Keywords: Siberian fir, regression model, forest type group, bonitet, growth rate table

\section{Introduction}

The Lower Angara region is one of the major reserves of Russia's forest resources. However, there still occurs natural forest degradation considering extensive forestry model, combined with climate change, fires, periodic massive pests impact and diseases. In most regions of Russia, there is an insufficient amount of sanitary and health-improving forestry activities aimed at developing dead forest stands which leads to a negative tendency towards the accumulation of standing dead trees. Thus, forests are losing their important ecological and economic components.

Many researchers had scientifically proved the fact that dark coniferous forest formation is more vulnerable to adverse impacts than the light coniferous forests $[1,2,3,4,5,6]$. At present, the impact of the factors mentioned above affects a vast territory of fir and cedar forests sustainability in the Lower Angara region. As practice shows, most of these forests will be left for natural growth and self-restoration, since the modern forest management system does not allow the timely implementation of sanitary and recreational activities properly.

It is common knowledge that succession often occurs through the change of species (which takes decades) or through successful coniferous species natural renewal with no period of replacing a forest space with birch and aspen. However, in both cases, the development patterns and the intensity of coniferous stand growth in certain forest site conditions persist in the long term. Therefore, creating regression models of forest growth and development involving the identification of site conditions is very important from a practical point of view and for environmental monitoring as well.

Studying the course of site growth, one can trace the pattern of taxation indicators changes throughout its life or to a specific (depending on the study purpose) age [7]. Growth rate tables (GRT) are the most straightforward and informative models of taxation parameters dynamics over time [8]. 
There are various approaches to growth rate tables building and their classification basis. Recently, considering mass inventory materials availability and climatic processes, the typological approach to the study of plantations growth and development has received additional interest $[9,10$, $11]$.

V.B. Kozlovsky and V.M. Pavlov [12, p. 23] pointed out that the main difficulty in using growth rate tables based on forest type is the change in environmental conditions and consequently, the forest type itself. At the same time, according to the authors, such tables represent the unique shape of the growth curve, in contrast to the bonitet curve. N.N. Svalov [13, p. 28] noted, "One should resolve the issue of choosing the type of tables and classification criteria for grouping material specifically, considering the economic goals and taxation objects". N.P. Anuchin [7] called for broader use of forest inventory materials (tables of age classes, bonitet, density and stocks; inventory descriptions) to compile growth rate tables for modal plantations. At the same time, V.B. Kozlovsky and V.M. Pavlov [12] believed that the practical use of tables for modal stands is somewhat limited. They make it possible to obtain a generalised idea of the studied area forests age dynamics and to substantiate the cutting age. However, in recent years, the problems of updating taxation indicators have become increasingly important, and a constant decrease in forest density makes such stands more common $[9,14]$. Thus, the statistical approach to the taxation indicators determination based on age classes makes it possible to estimate mean forest stand attributes reliably.

The study of the growth rate of the most common fir formation forest types, growing within the boundaries of the Yenisei forestry of the Krasnoyarsk Krai, was carried out in frames of the present research. On the mathematical analysis basis, regression models of growth processes have been developed, which can be useful for adjusting and improving forest inventory standards and diverse environmental monitoring activities.

\section{Materials and Methods}

Bonitet was taken as the basis for identifying forest growing conditions as a universal indicator of a habitat quality [7]. The object of the study was Siberian fir stands of the third bonitet class, growing in the conditions of the West Siberian southern taiga plain forest area of the Lower Angara region on the territory of the Yenisei forestry of the Krasnoyarsk Krai [15]. These plant communities occupy $36.3 \%$ of coniferous plantations of the forestry and are considered modal forest stands. Within given productivity of forest stands, the most common types of forest are mossy and forb groups.

The research methodology is based on the developments of N.V. Tretyakov, supplemented by I.V. Semechkin [14]. The study is based on the materials of the mass inventory of 3491 stands (1367 stands belonged to the forb group of forest types, and 2124 stands belonged to the mossy group of forest types). Stands with a predominance of the fir element (proportion of fir of at least three units in the total composition of the stand) were selected for sampling. Such stands, growing on the study territory, are characterised by the mean taxation indices shown in Table 1.

Table 1. Mean taxation indices of the fir stands of the third bonitet class.

\begin{tabular}{cccccc}
\hline $\begin{array}{c}\text { Forest type } \\
\text { group }\end{array}$ & Age, years & Height, $\mathbf{m}$ & Diameter, $\mathbf{c m}$ & Density & Stock, $\mathbf{m}^{3} / \mathbf{h a}$ \\
\hline Forb & $103 \pm 1,2$ & $18.4 \pm 0,2$ & $20.0 \pm 0.2$ & 0.62 & $177 \pm 2$ \\
Mossy & $99 \pm 0,9$ & $18.7 \pm 0,1$ & $20.2 \pm 0.1$ & 0.67 & $201 \quad \pm 1$ \\
\hline
\end{tabular}

Primarily, the initial data of mass inventory materials by the following indicators: age, height, diameter, stock, density were subjected to statistical processing. The processing formulas follow standard statistical approaches. The selection of regression models was carried out using the "Curve Expert 1.3» curve fitting system.

\section{Results and Discussion}


In the absence of stress factors (fire, pests, weather conditions) leading to the mass death of trees, fir stands naturally develop as uneven-aged stands. There are all transition stages from self-seeding and undergrowth to overmature trees. When overmature trees reach the age of natural death, young ones developed from the undergrowth under the maternal canopy replace them. The forest-forming process occurs continuously in fir stands, but its intensity changes over time since it depends on many constantly changing factors. Thus, fir forests structure is also continually changing: at some stages, relatively young trees (under the age of 50-60 years) prevail in a stand, at others - older ones (up to 80-120 years). At the same time, the taxation indicators of the stand change, which affects other components of the plantation. Therefore, fir stands undergo certain development stages [16].

Although one fir stand can include several generations of trees, its main parameters (development pattern, productivity and taxation characteristics) do not change much over time, since they are determined by the quality of forest growing conditions.

It can be assumed based on the data of various sources $[16,17,18]$ that the studied fir stands formed by previous generations of undergrowth which survived logging or after the natural decay of birch and aspen forests.

According to the results of the study, the statistical analysis of the main taxation characteristics showed a specific pattern for naturally developing forest stands; namely, more aged stands demonstrate the decrease in indicators variability and the increase in experiment accuracy.

Initially, a forecast of age-related changes in mean height, diameter and stocks values in modal fir stands was carried out. It was established that the studied correspondences reach a high degree of approximation using the Hoerl Model function (Equation 1):

$$
y=a b^{x} \cdot x^{c}
$$

Table 2 shows the coefficients of the equations and indicators of their approximation.

Table 2. Hoerl Model regression function parameters

\begin{tabular}{|c|c|c|c|c|c|}
\hline \multirow{2}{*}{ Parameters } & \multicolumn{3}{|c|}{ Equation coefficients } & \multirow{2}{*}{$\begin{array}{l}\text { Levelling } \\
\text { factor }\end{array}$} & \multirow{2}{*}{$\begin{array}{c}\text { Standard } \\
\text { error }\end{array}$} \\
\hline & $\mathbf{a}$ & b & c & & \\
\hline \multicolumn{6}{|c|}{ Forb group of forest types } \\
\hline Height, m & 0.127 & 0.993 & 1.266 & 0.987 & 0.855 \\
\hline Diameter, $\mathrm{cm}$ & 0.068 & 0.992 & 1.429 & 0.971 & 1.674 \\
\hline Stock, $\mathrm{m}^{3} / \mathrm{ha}$ & 0.090 & 0.988 & 1.954 & 0.972 & 16.332 \\
\hline \multicolumn{6}{|c|}{ Mossy group of forest types } \\
\hline Height, m & 0.196 & 0.994 & 1.148 & 0.989 & 0.652 \\
\hline Diameter, $\mathrm{cm}$ & 0.158 & 0.995 & 1.188 & 0.970 & 1.433 \\
\hline Stock, $\mathrm{m}^{3} / \mathrm{ha}$ & 0.186 & 0.989 & 1.783 & 0.967 & 16.509 \\
\hline
\end{tabular}

Figure 1 shows the age-related change in taxation parameters of modal Siberian fir stands in the Lower Angara region.

At the second stage, sketches of growth rate tables were developed for groups of forest types, using the data obtained by tabbing of the Hoerl Model function. The regression equation works in the age range from 20 to 200 years. 

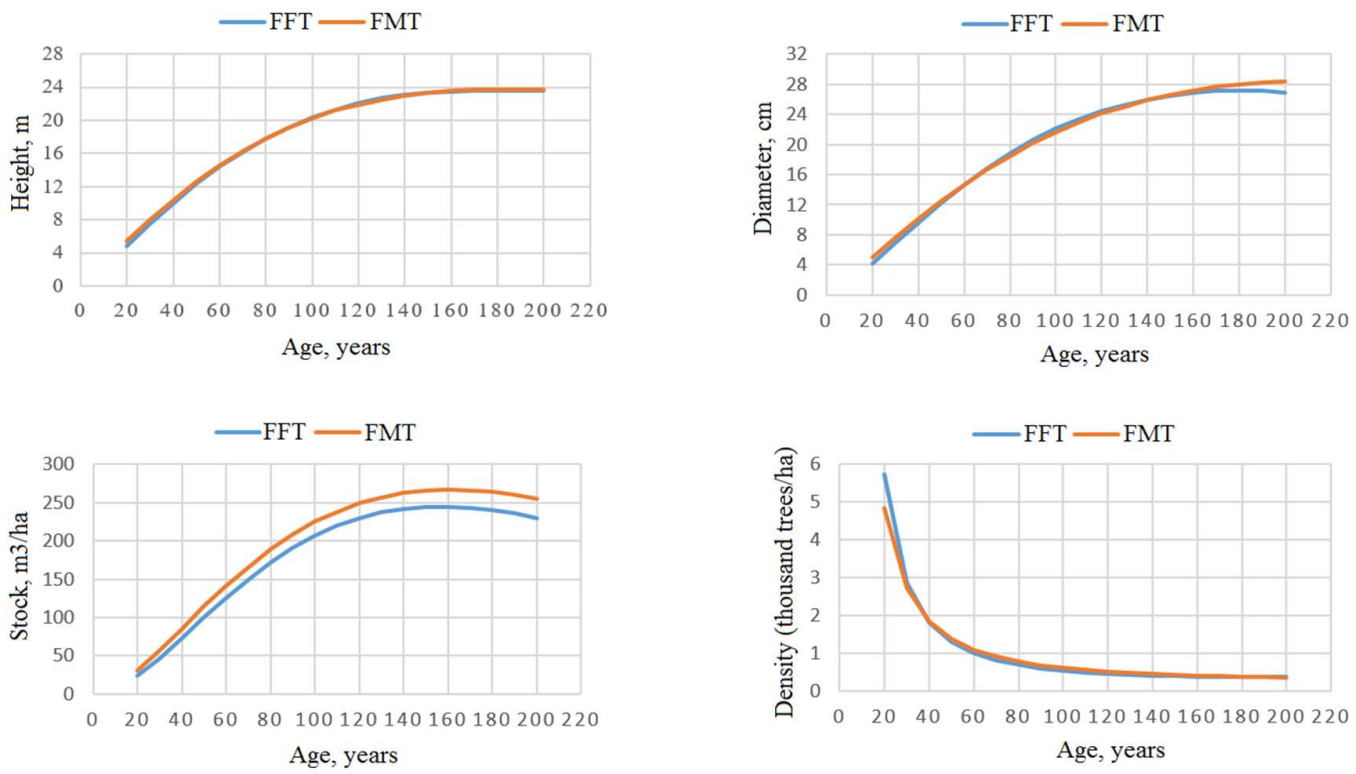

Figure 1. Changes in taxation parameters of the modal Siberian fir stands with age in the Lower Angara region (FFT - fir stand of forb group of forest types, FMT - fir stand of mossy group of forest types)

Other taxation indicators for constructing the studied site standards were calculated using generally accepted taxation formulas of correspondence between them [9, 14]. The results of the forecast of the course of growth for the forb and mossy forest types groups are presented in Tables 3 and 4 , respectively.

Table 3. Sketch of the growth rate table for the modal Siberian fir stands of the forb group of forest types

\begin{tabular}{|c|c|c|c|c|c|c|c|c|}
\hline \multirow{2}{*}{$\begin{array}{l}\text { Age, } \\
\text { years }\end{array}$} & \multicolumn{2}{|c|}{ Mean } & \multirow{2}{*}{$\begin{array}{l}\text { Form } \\
\text { factor }\end{array}$} & \multirow{2}{*}{$\begin{array}{c}\text { Tree } \\
\text { volume, } \mathbf{m}^{3}\end{array}$} & \multirow{2}{*}{$\begin{array}{l}\text { Density, } \\
\text { trees/ha }\end{array}$} & \multirow{2}{*}{$\begin{array}{l}\text { Stock, } \\
\mathrm{m}^{3} / \mathrm{ha}\end{array}$} & \multicolumn{2}{|c|}{$\begin{array}{c}\text { Stock change, } \\
\mathrm{m}^{3} / \mathrm{ha}\end{array}$} \\
\hline & $\begin{array}{c}\text { height, } \\
\text { m }\end{array}$ & $\begin{array}{c}\text { diameter, } \\
\mathrm{cm}\end{array}$ & & & & & mean & current \\
\hline 20 & 4.8 & 4.2 & 0.64 & 0.0042 & 5746 & 24 & 1.2 & - \\
\hline 30 & 7.5 & 6.9 & 0.59 & 0.0165 & 2870 & 47 & 1.6 & 2.3 \\
\hline 40 & 10.0 & 9.6 & 0.56 & 0.0406 & 1803 & 73 & 1.8 & 2.6 \\
\hline 50 & 12.3 & 12.2 & 0.54 & 0.0778 & 1285 & 100 & 2.0 & 2.7 \\
\hline 60 & 14.4 & 14.6 & 0.52 & 0.1270 & 992 & 126 & 2.1 & 2.6 \\
\hline 70 & 16.2 & 16.8 & 0.51 & 0.1858 & 808 & 150 & 2.1 & 2.4 \\
\hline 80 & 17.8 & 18.8 & 0.50 & 0.2508 & 686 & 172 & 2.2 & 2.2 \\
\hline 90 & 19.2 & 20.6 & 0.50 & 0.3183 & 600 & 191 & 2.1 & 1.9 \\
\hline 100 & 20.4 & 22.1 & 0.49 & 0.3849 & 538 & 207 & 2.1 & 1.6 \\
\hline 110 & 21.3 & 23.4 & 0.49 & 0.4475 & 492 & 220 & 2.0 & 1.3 \\
\hline 120 & 22.1 & 24.5 & 0.48 & 0.5037 & 457 & 230 & 1.9 & 1.0 \\
\hline 130 & 22.7 & 25.3 & 0.48 & 0.5517 & 431 & 238 & 1.8 & 0.7 \\
\hline 140 & 23.1 & 26.0 & 0.48 & 0.5905 & 411 & 242 & 1.7 & 0.5 \\
\hline 150 & 23.4 & 26.5 & 0.48 & 0.6195 & 395 & 245 & 1.6 & 0.2 \\
\hline 160 & 23.5 & 26.9 & 0.48 & 0.6387 & 384 & 245 & 1.5 & 0.0 \\
\hline 170 & 23.6 & 27.1 & 0.48 & 0.6486 & 375 & 243 & 1.4 & -0.2 \\
\hline 180 & 23.5 & 27.1 & 0.48 & 0.6497 & 370 & 240 & 1.3 & -0.3 \\
\hline 190 & 23.4 & 27.1 & 0.48 & 0.6430 & 366 & 236 & 1.2 & -0.5 \\
\hline 200 & 23.1 & 26.9 & 0.48 & 0.6296 & 365 & 230 & 1.1 & -0.6 \\
\hline
\end{tabular}


Table 4. Sketch of the growth rate table for the modal Siberian fir stands of the mossy group of forest types

\begin{tabular}{|c|c|c|c|c|c|c|c|c|}
\hline \multirow{2}{*}{$\begin{array}{l}\text { Age, } \\
\text { years }\end{array}$} & \multicolumn{2}{|c|}{ Mean } & \multirow{2}{*}{$\begin{array}{l}\text { Form } \\
\text { factor }\end{array}$} & \multirow{2}{*}{$\begin{array}{c}\text { Tree } \\
\text { volume, } \mathbf{m}^{3}\end{array}$} & \multirow{2}{*}{$\begin{array}{l}\text { Density, } \\
\text { trees/ha }\end{array}$} & \multirow{2}{*}{$\begin{array}{l}\text { Stock, } \\
\text { m³/ha }\end{array}$} & \multicolumn{2}{|c|}{$\begin{array}{c}\text { Stock change, } \\
\mathrm{m}^{3} / \mathrm{ha}\end{array}$} \\
\hline & $\begin{array}{c}\text { height, } \\
\text { m }\end{array}$ & $\begin{array}{c}\text { diameter, } \\
\mathrm{cm}\end{array}$ & & & & & mean & \\
\hline 20 & 5.4 & 5.0 & 0.62 & 0.0064 & 4837 & 31 & 1.6 & 2.1 \\
\hline 30 & 8.0 & 7.6 & 0.58 & 0.0210 & 2718 & 57 & 1.9 & 2.6 \\
\hline 40 & 10.4 & 10.1 & 0.56 & 0.0466 & 1835 & 85 & 2.1 & 2.8 \\
\hline 50 & 12.6 & 12.5 & 0.54 & 0.0832 & 1370 & 114 & 2.3 & 2.8 \\
\hline 60 & 14.6 & 14.7 & 0.52 & 0.1295 & 1089 & 141 & 2.4 & 2.7 \\
\hline 70 & 16.3 & 16.7 & 0.51 & 0.1836 & 905 & 166 & 2.4 & 2.5 \\
\hline 80 & 17.8 & 18.5 & 0.51 & 0.2429 & 777 & 189 & 2.4 & 2.2 \\
\hline 90 & 19.1 & 20.2 & 0.50 & 0.3049 & 683 & 208 & 2.3 & 2.0 \\
\hline 100 & 20.2 & 21.6 & 0.49 & 0.3672 & 612 & 225 & 2.2 & 1.7 \\
\hline 110 & 21.2 & 22.9 & 0.49 & 0.4277 & 558 & 238 & 2.2 & 1.4 \\
\hline 120 & 21.9 & 24.1 & 0.49 & 0.4845 & 514 & 249 & 2.1 & 1.1 \\
\hline 130 & 22.5 & 25.0 & 0.48 & 0.5363 & 480 & 257 & 2.0 & 0.8 \\
\hline 140 & 23.0 & 25.9 & 0.48 & 0.5819 & 451 & 263 & 1.9 & 0.5 \\
\hline 150 & 23.3 & 26.6 & 0.48 & 0.6207 & 428 & 266 & 1.8 & 0.3 \\
\hline 160 & 23.6 & 27.2 & 0.48 & 0.6523 & 409 & 267 & 1.7 & 0.1 \\
\hline 170 & 23.7 & 27.7 & 0.48 & 0.6767 & 393 & 266 & 1.6 & $-0,1$ \\
\hline 180 & 23.7 & 28.0 & 0.47 & 0.6938 & 380 & 264 & 1.5 & $-0,2$ \\
\hline 190 & 23.6 & 28.3 & 0.47 & 0.7041 & 369 & 260 & 1.4 & -0.4 \\
\hline 200 & 23.5 & 28.4 & 0.47 & 0.7080 & 360 & 255 & 1.3 & -0.5 \\
\hline
\end{tabular}

Analysis of taxation indicators within each group of forest types allows us to conclude that the productivity of mossy fir stands is higher than the productivity of forb fir stands. The stock at the interval from the young growth stage to the overmature stage varies from 31 to $255 \mathrm{~m} 3 / \mathrm{ha}$, while in the forb fir stands its values range from 24 to $230 \mathrm{~m} 3 / \mathrm{ha}$. The values of the mean stock increase also vary. Forest stands are similar in terms of the trees density thinning dynamics. Trees maturity stage begins at the age of 170 years in both stands.

\section{Conclusions}

As a result of the research regression model of the growth rate has been developed for modal fir stands concentrated in the Lower Angara region (Yenisei forestry of the Krasnoyarsk Krai). The regression model makes it possible to predict the taxation indicators dynamics and reproduce the successional development of forest stands of the third bonitet class of the forb and mossy groups of forest types.

The Hoerl Model function approximates the growth rate of the study plantations with high precision. Sufficiently high accuracy is evidenced by the correlation coefficients from 0.97 to 0.99 for mossy and forb groups of forest types, respectively, as well as by a small standard error (not exceeding $7 \%$ ).

The practical importance of such growth rate tables is indisputably high, which characterise the features of the development of the modal stand in certain forest conditions in mathematical progression. In addition to the advantages mentioned above, such tables make it possible to detail environmental observations data related to the identification of phytomass accumulation per unit area, including forest pathological monitoring of areas where favourable forage base for pests is formed; the dynamics of carbon deposition and emission by fir stands; as well as adjusting a study area taxation standards.. 
Author Contributions: Formal analysis, P.V.M. and S.M.S.; investigation, P.V.M. and S.M.S.; methodology, S.M.S. and A.A.G.; writing-original draft, S.M.S.; writing-review \& editing, P.V.M. and S.M.S. All authors have read and agreed to the published version of the manuscript.

Funding: The research was carried out within the projects «Fundamentals of forest protection from entomo- and fittings pests in Siberia» (№ FEFE-2020-0014) within the framework of the state assignment, set out by the Ministry of Education and Science of the Russian Federation, for the implementation by the Scientific Laboratory of Forest Health.

Acknowledgments: We would like to thank the Krasnoyarsk center for collective use for the equipment provided.

Conflicts of Interest: The authors declare no conflict of interest. The funders had no role in the design of the study; in the collection, analyses, or interpretation of data; in the writing of the manuscript; or in the decision to publish the results

\section{References}

1. Nevolin O. A. On Decay and Downfall of Overmature Spruce Forests in Beresnik Forestry Unit of Arkhangelsk Region Forest Journal 2005, Volume 6, pp. 7-22 [in Russian].

2. Storozhenko V. G. Coarse woody debris in natural forests of Russian plane (Moscow: KMK Scientific Press Ltd.) 2011, 122 p [in Russian].

3. Nuorteva P. The role of air pollution and climate change in development of forest insect outbreaks - guest editorial : Workshops "Eff. Possible Glob. Acta phytopathol. et entomol. hung 1997, Volume 32 (1-2), pp. 127-128.

4. $\quad$ Rigling A. Waldfohrenbestande im Umbruch Wald und Holz 1999, Volume 80(13), pp. 8-12.

5. Vertui F. Tagliaferro F. Scots pine (Pinus sylvestris L.) die-back by unknown causes in the A'osta Valley, Italy Chemosphere 1998, Volume 36(4-5), pp. 1061-1065.

6. Woodward S. Causes of decline in United Kingdom broadleaved stands Possible Limitation of Decline Phenomena in Broadleaved Stands (Warsaw) 2006, pp 21-27.

7. Anuchin N. P. Forest taxation: textbook for universities (Moscow: Lesnaya promyshlennost) 1982, 552 p. [In Russian].

8. Shevelev S. L. Forest taxation reference book for the southern taiga forests of central Siberia (Moscow: ARRISMF) 2002, $166 \mathrm{p}$

9. Vais A .A. Dynamics of forest inventory indices of fir plantations of Kansk forest-steppe after continuous logging Coniferous boreal zone 2019, Volume XXXVII (5), pp. 102-107 [In Russian].

10. Ziganshin R. A. Woodland: Geographical and Forest Inventory Indications and Criteria Siberian Journal of Forest Science 2014, Volume 1, pp 50-68 [In Russian].

11. Uss E.A. The course of growth of spruce plantations in Belarus by bonitet in the context of the main types of forest Actual problems of the forest complex 2014, Volume 38 [in Russian].

12. Kozlovsky V. B., Pavlov V. M. Stand development of main forest-forming species of the USSR. Moscow.: Lesnaya promyshlennost) 1967, 327 p [In Russian].

13. Svalov N. N. Simulation of productivity of stands and theory of forest management (Moscow: Lesnaya promyshlennost) 1979, $216 \mathrm{p}$ [in Russian].

14. Batvenkina T. V. Research of the rate of change of average taxational indicators of pine stands of various completeness and density Forest Taxation and Forest Management 2001, Volume 1(30), pp. 33-36 [In Russian].

15. Forestry regulations of the Yenisei forestry of the Krasnoyarsk Territory Krasnoyarsk Krai. Official website (Krasnoyarsk : Ministry of Natural Resources and Forest of the Krasnoyarsk Region). 2018, Retrieved from http://www.krskstate.ru/government.

16. Falaleev E.N. Fir Forests of Siberia: Their Complex Use (Moscow: Lesnaya promyshlennost). 1964, 213 p [in Russian].

17. Andreev G. V. Analysis of the Typological Structure of the Forest Lands within the Southern Ural Province of South Taiga and Mixed Forests // Contemporary Issues of the Population, Historical and Applied Ecology: Conference Materials (Ekaterinburg: Ekaterinburg Publishing House) 1998, pp. 231-232 [In Russian]. 
18. Andreev G. V., Ivanova N. S. Natural under-canopy renewal of Siberian spruce and fir in the subzone of Southern Urals dark-coniferous forests Forest valuation. 2008, Volume 2 (40), pp. 25-28 [In Russian]. 